\title{
Puppet Art Extracurricular for Education Noble Values of Javanese Culture in Elementary Schools
}

\author{
Ria Ratnawati ${ }^{1}$, Slamet Subiyantoro ${ }^{2}$, Budi Usodo ${ }^{3}$ \\ 1,2,3 Faculty of Teacher Training and Education, Universitas Sebelas Maret \\ Corresponding email: riaratnawati01@gmail.com
}

\begin{abstract}
The entry of various advances in the political, economic, social, cultural, and technological can have a negative impact if we cannot respond properly. One of the negative impacts is the lack of understanding and preservation of puppetry among the younger generation. Many students today are unable to understand the elements of puppetry both from the perspective of science or character education which is full of the noble values of Javanese culture. This is one of the reasons for the importance of holding puppetry extracurricular activities in elementary schools. This study aims to describe the extracurricular implementation of puppetry in elementary schools. This research is a qualitative method with a descriptive design. Data collection techniques using interviews and documentation. The data validity technique used triangulation. The results of this study are the implementation art of puppetry in elementary schools, which consisted of students playing the puppets, learning the wayang story, playing gamelan instruments, and singing Javanese songs. The conclusion of this study is the art of puppetry needs to be introduced and implemented in elementary schools because it has the noble values of Javanese culture which are beneficial for the formation of student character. The implication of this research is extracurricular art of puppetry has noble values of Javanese culture that can be developed through the application of various activities during learning. Besides, students can participate in preserving Javanese traditional culture and arts in a series of puppet art extracurricular activities.
\end{abstract}

Keywords: Elementary School, Extracurricular, Javanese culture, Puppetry Art

\section{INTRODUCTION}

Education has a function as a process of social change that accommodates the social character of society, not just the transfer of information about knowledge from educators to students, but a character-building process which has three main missions, namely, an inheritance of knowledge (transfer of knowledge), cultural inheritance (transfer of culture), and inheritance of value (transfer of value) (Nugroho, 2016: 33) [15]. Learning is said to be successful when the activities that take place in the school can facilitate students in the process of transfer of value (Amri 2016: 49) [3]. The inheritance of values and knowledge can be carried out through culture-based activities, one of which is Javanese culture. Javanese culture has characteristics by prioritizing balance, harmony, and harmony in life. The preservation of Indonesian culture is in line with the Government Regulation of the Republic of Indonesia Number 19 of 2005 which mandates that cultural content does not only exist in one subject because culture itself covers all aspects of the life of the Indonesian nation. However, currently what is happening is that students have less knowledge of Javanese traditional arts and culture. The fact is that students today have forgotten traditional arts and Javanese noble values because no one has taught them, the environment has changed, technological developments and advances, as well as various factors of cultural change in society (Susiatik, 2017: 65) [28]. The influence of globalization harms the culture of the Indonesian nation, with the erosion of regional cultural values and the spirit of nationalism caused by the clash of cultural values and those from the outside, causing the Indonesian people to lose their identity (Danoebroto, 2012: 94) [8]. The decline in awareness of moral values that have been passed down through generations by ancestors has begun to be shifted by norms and rules from the west which tend not to be following the conditions of our society. Not everyone leaves their culture, but the next generation is shrinking because the majority think that the local culture is not in harmony with current conditions which tend to lead to modern culture (Rachmadian 2015: 12) [18]. Therefore, the 
implementation of cultural preservation must be based on the belief that local culture is the embodiment of self from society so that it can foster a strong sense of pride, self-esteem, and self-confidence (Clifton 2012: 716) [7]. One of the Javanese cultures that have less interest is the art of puppetry. In 2003, wayang was recognized by UNESCO as an oral and intangible cultural heritage work of humanity (Sulaksono, 2018) [24], so it needs to be preserved and preserved for the younger generation. With so many types of wayang in Indonesia, of course, preserving the art of wayang kulit is not an easy thing, especially since this traditional art is not so popular among young people (Parikesit, 2016) [16]. Puppetry is one of the Javanese cultural treasures included in Widya Art. Widya is a whole knowledge that contains philosophy, both of which means seeking wisdom (ngudi wicaksana), and which means seeking perfection (ngudi kasampurnan) and education to achieve its goals (Ciptoprawiro 2000: 82) [6]. Puppets is a symbol of traditional Javanese worldview that serves as an art, religious ritual, and has been a medium of idea submission for more than a thousand years. However, the fact is that not all students understand the elements of wayang, both in terms of science or character education, starting from wayang characters, the tools used, and even the stories in wayang. Puppetry is an activity carried out by puppeteers assisted by pengrawit, pesinden, and other wayang presentation tools (Supriyono 2008: 1) [26]. The art of puppetry is called adi luhung traditional art, which means it is very beautiful and has great value. Wayang performances can be seen from the aspect of character education, and the stories will show philosophical values. The noble values of wayang characters can become education and behavioral development that students must have in life. Wayang is a work of art and culture of the highest value. Javanese people think that the wayang story contains guidelines and teachings of life that should be used as a guide for life (Harimurti 2001: 60) [13]. Wayang contains Javanese noble values, one of the characteristics of which is that at the end of each story the good and the evil always win. It contains the teaching that good deeds will be superior, while bad deeds will always accept defeat. The story in this puppet can be applied as a way to cultivate and preserve Javanese noble values that are easier for students to understand. This is one of the reasons for the importance of holding puppetry extracurricular activities in elementary schools. The extracurricular art of puppetry in elementary schools can be used as a forum for education and preservation of the noble values of Javanese culture.

Related research was conducted by Purwanto (2019) regarding the internalization of religious values in puppeteer education. This study aims to examine the process of internalizing the values by religious teachings in puppeteer education, students' responses and perceptions in the process of internalizing religious values in puppeteer education, and the attainment of internalizing religious values in puppeteer education in dalang schools [17]. Another study conducted by Putra (2015) examined the implementation of Javanese culturebased education in students of SD Taman Muda Ibu Pawiyatan Taman Yogyakarta. This study aims to describe the implementation of Javanese culture-based education for students of SD Taman Muda Ibu Pawiyatan Taman Yogyakarta. Another study by Grahita (2014) on Identification of The Character Figures Visual Style in Wayang Beber of Pacitan Painting. This study describes a transformation of wayang beber of Pacitan character figure's visual style and identification of its features. The purpose is to compile artistic knowledge for preserving wayang beber traditions. As a result, found four important features of the visual style; those are stylized shape, distorted proportion, outline drawing, and polychromatic color [12]. The fourth relevant research is conducted by Brits (2014) with the title Exploring the Use of Puppet Shows in Presenting Nanotechnology Lessons in Early Childhood Education. Puppets were selected as a medium because they facilitate social interaction, thereby enhancing communication through role-playing, imagination, story-telling, and listening for young children. It is therefore the ideal interactive teaching aid. Life-size boy and girl puppets were manufactured in addition to different animals and a Nanoshi character with his magnificent instruments. The Nanoshi character invites the children to his small, small world where material acts differently, gold has extraordinary colors, and a very thin, thin wire can be very strong. The children are constantly encouraged by the puppets to ask questions and assist in solving problems [5]. By research conducted by Benninga (2003: 19) on the relationship between character education and school achievement in several elementary schools in California, it is concluded that schools, where character education is seriously taught, tend to have high academic achievement [4]. Relevant research is conducted by Divya (2015) with the title of a study to assess the effectiveness of puppet show on knowledge regarding selected mosquito-borne disease among children in the selected village at Nellore. In the pre-test $16(27 \%)$ had moderate knowledge and 44(73\%) had inadequate knowledge. The scores of the post-test indicated an increase in knowledge levels of the primary school children i.e. 11(18\%) had adequate knowledge followed by $35(59 \%)$ had moderate knowledge, 14(23\%) had inadequate knowledge [9].

The purpose of this research is the implementation of extracurricular activities based on traditional Javanese art, namely the art of puppetry in elementary schools, which can be used as a means of instilling and preserving Javanese noble values through the application of various activities during the learning of wayang games and stories in wayang. In addition to planting attitudes and knowledge in the extracurricular activities of puppetry, students can also participate in preserving traditional 
Javanese arts in a series of puppet art extracurricular activities.

\section{METHODS}

This type of research is qualitative research. This research is a descriptive study with a case study research design. Sugiarto (2015: 12) that "a case study is a type of in-depth research on individuals, groups, institutions, and so on within a certain time" [22]. The problem examined in this study is the extracurricular implementation of the art of puppetry in preserving and knowledge of the noble values of Javanese culture. The research targets include activities in the art of puppetry extracurricular activities. The data sources are school principals, teachers, and students. The selection of SD Muhammadiyah 1 Ketelan Surakarta as a research location is one of the schools that are active in developing and preserving Javanese cultural values through various activities, including extracurricular batik, dance, musical instruments, and puppetry.

The subjects in this study were school principals, curriculum representatives, class teachers, parents of students, extracurricular coordinators, extracurricular trainers for the art of puppetry, and students who took puppetry extracurricular activities at SD Muhammadiyah 1 Ketelan Surakarta. Case study data were obtained through interviews, observation, and studying various documents related to the topic under study (Sugiarto, 2015: 12) [22]. Primary data in this study are the results of interviews and observations from parties related to the implementation of the puppet art extracurricular. Secondary data in this study were school profiles and photos of puppet art extracurricular activities. This study uses data forms including audio recordings, video recordings, field notes, photos, and data from books.

The main data source was audio-recorded and recorded interviews. The second data source is the places and events obtained from photos and field notes. The third source is written sources, namely additional material from books, journals, documents, and other sources related to extracurricular activities in elementary schools. Data were collected using observation, interviews, and content analysis. Interviews were conducted using purposive sampling and snowball sampling techniques.

This study validated the data by using triangulation techniques of sources and methods. Triangulation is a data validity checking technique by utilizing something other than data for checking purposes or as a comparison of the data (Sugiyono, 2017: 372) [23]. The data were validated using triangulation of sources and methods by 1) comparing the results of interviews with existing theories; 2) comparing the data from the photo documentation of the activity with the results of the interview data; 3 ) comparing the results of the interview with the contents of the documents related to the art of puppetry extracurricular activities
The position of the researcher is as a planner, implementer, data collector, analyzer, and reporter of research results. The research data were collected and analyzed descriptively qualitatively. The analysis process was carried out using qualitative models from Miles and Huberman (Sugiyono, 2017: 337) [23], namely data reduction, presentation of data descriptions, and concluding. The extracurricular activities of puppetry were analyzed continuously from the beginning of data collection to the conclusion. Verification takes place from start to finish. The analysis process occurs interactively to test the relationship between components continuously during the study. Using such analytical techniques, the conclusions will be properly tested.

\section{RESULT AND DISCUSSION}

Extracurricular activities are carried out to develop certain aspects contained in the implemented curriculum, including those related to how the actual application of the knowledge taught by students is by the demands of their needs and the environment (Mulyono 2009: 186) [14]. The values of local cultural wisdom can be integrated into children's learning at school (Safitri 2017: 162). The noble values of local culture and culture can be the basis for character education (Surtikanti 2017: 1) [27]. The combination of education and culture in the learning process will create meaningful learning (Syafitri 2017: 162) [29]. Widodo (2013: 142) states that culture is the manifestation of human character [31].

Local knowledge can be understood as the ideas of locals that are wise, full of wisdom, good value, embedded, and followed by members of the community (Sartini 2004: 111) [20]. Noble values that come from local customs and culture should be prioritized to be internalized to students through character education. The essence of character education is not just teaching knowledge to students about good and bad. Character education is a process of instilling positive values in students through various appropriate methods and strategies.

The noble values contained in the customs and culture of the Indonesian ethnic groups have been studied and summarized into one. Based on this study, the Ministry of National Education in 2010 has identified values that will be internalized to the nation's generation through character education. These values include religion, honesty, tolerance, discipline, hard work, creativity, independence, democracy, curiosity, national spirit, love for the country, respect for achievement, friendship, love of peace, love to read, care for the environment, care for social and responsibility.

Elementary school can be used as a forum for fostering and fostering quality students without having to ignore the regional cultural characteristics it has. One of the leading extracurricular activities in elementary schools is puppetry. This extracurricular is unique as a 
means of developing students' interests and talents through various activities related to Javanese culture. However, in modern entertainment, wayang kulit performances are increasingly marginalized (Foley, 2015) [11]. One of the causes is a lack of awareness of the values of locality and cultural preservation. Therefore, the preservation of traditional arts is necessary so that local values do not shift (Ricklefs 2012) [19]. The implementation of puppet extracurricular activities is one of the activities outside of learning that can be used in teaching the noble values of the culture that is owned so that it continues to be preserved.

The art of puppetry can be developed in various educational institutions which are expected to have an impact on the preservation of local culture. Supangah (2002: 12) states that the art of wayang is something related to wayang, including guidance, appreciation, support, criticism, and knowledge of wayang [25]. The definition of wayang is broader because it is an ancient art and has survived to this day. Wayang kulit is not only entertaining but also a necessity to live up to philosophical values. In wayang stories, each character is a reflection or representation of human attitudes and characteristics in general (Aizid, 2012: 34) [2].

Puppetry art contains the noble values of Javanese society that students can apply in their daily lives, such as religion, nationalism, integrity, cooperation, and independence. Wardani (2016: 52) states that the values of local wisdom that appear in the wayang wong stories are the values of tenacity, patience, nrimo ing pandum, and sincerity. Stories in puppetry can be used as examples to instill noble moral values in students, various morals, and attitudes through the plays of various puppet characters in puppetry to provide a picture of human life to students [30].

Javanese cultural values can be instilled and learned since childhood, starting from the family and the surrounding environment through the cultivation of character. Endraswara (2006: 23) describes the cultivation of Javanese character through several forms, namely the formation of moral harmony, the formation of morals for the virtues of life, the formation of manners, and the formation of self-control [10]. Alhklak this harmony is intended to instill the principle of respect related to character related to unggah-ungguh and Javanese karma and instill a harmony of life. The formation of morals for the virtues of life is intended to instill a wise and honest character.

The formation of good manners is intended to form an attitude of inferiority and always being modest. Forming good and correct unggah-ungguh and manners that refer to good rules to educate community politeness. Forming a character of self-control, in carrying out something Javanese society has the principle that it is better to do the work, it is better if it is done with full planning, calculation, not in a hurry as long as it reaches the goal. Cultivating the ora nggaya and nrima characters, these attitudes describe the Javanese life attitude at work. It is also related to efforts to achieve a goal. This attitude calls for restraint to always be not arrogant and accepting.

The formation of morality and attitudes of the Javanese people can be preserved through various activities in life, one of which is the extracurricular art of puppetry in elementary schools. Through extracurricular activities based on traditional Javanese arts, namely puppetry in elementary schools, it is hoped that the noble values of Javanese culture can be developed through the application of various activities during learning. Besides, students can participate in preserving Javanese traditional culture and arts in a series of puppet art extracurricular activities. Activities that can be carried out to develop Javanese noble value-based education through the art of puppetry extracurricular activities, for example teaching students to tolerate other people and have a good character so that they can be imitated associated with stories in wayang.

Puppet art extracurricular activities are carried out every Wednesday after learning. The implementation is in conjunction with the musical arts extracurricular activities. Meanwhile, the strategy adopted in handling each competition event is to understand in advance how the criteria of the competition will be faced, attend every event or activity related to puppetry, as well as compaction of training hours more intensively when approaching the race day. Implementation Of Puppetry Art extracurricular in Elementary School has three steps:

\section{a. Planning}

Planning in puppetry extracurricular activities involves the principal, teachers, extracurricular trainers, parents, and the school committee. Afandi (2009: 147) states that planning is a projection (estimate) of what is needed to achieve valid and valuable goals [1]. The role or involvement of parents in the extracurricular activities of puppetry is based on the existence of parents who strongly support their children to take part in extracurricular activities. This has an impact on students' enthusiasm and consistency in extracurricular puppetry activities.

The puppet extracurricular activity program goes through the planning stages starting from the active program planning of the competition, finance, training activities, recruitment, and selection of extracurricular members at the beginning of the school year. To achieve the stated organizational goals, extracurricular activities have long and short-term work programs. Extracurricular activities have rules that apply to students in each of their activities. The rule is that students who participate in extracurricular activities must use good and polite language, maintain their daily actions, behavior, and attitudes both at home and at school. As for the consequences are given to students who are found to have 
committed violations, namely getting a follow-up in the form of a direct or indirect warning.

\section{b. Implementation}

The implementation of puppetry extracurricular activities includes starting with the formation of an organizational structure carried out at the end of each semester. Organizational structure is related to tasks, with the aim that each party can be responsible for their work. The parties involved in each formation of an organizational structure for extracurricular activities are the principal, school committee, and teachers. The extracurricular coach or teacher is in charge of fostering and training students in wayang games. The exercise is carried out every Wednesday for 2 hours after learning in class is finished.

Based on the results of interviews and documentation, puppetry extracurricular activities are carried out in an orderly manner and following the applicable schedule. Management methods in extracurricular activities consist of continuous training, with this method students easily accept, understand, and practice material related to puppetry. Coordination, in facing each school competition consisting of the principal, teachers, and parents of students, first coordinate with the competition to be followed regarding the puppet stories that will be displayed in the competition.

The rules applied in extracurricular activities include discipline in preparing for each competition. The learning methods used are theory and practice. High motivation is very important for every student in puppet extracurricular activities. The reality that exists in society is the development of an increasingly modern era that can make students embarrassed to explore Javanese art that has become a tradition. Many attempts have been made to motivate students in puppetry art activities. Motivation is carried out in every exercise and when students get achievements at a competition event.

Routine training is carried out by students with an extracurricular teacher who is one of the puppeteers in Surakarta and a puppet scholar named Ki Agung. Every puppet show fostered by Ki Agung always inserts a moral message in it, there are messages from the five main characters, from the side of religion, nationalism, integrity, cooperation, and independence. The supporting factor from this extracurricular teacher is one of the supporting factors for the extra progress of puppetry.

The art of puppetry contains Javanese noble values, one of its characteristics, namely that in every ending of the story always wins good and overcomes evil. It contains teaching that good deeds will excel, while evil deeds will always accept defeat. The stories in this puppet can be applied as a way of planting and preserving Javanese noble values that are easier for students to understand.
Based on the results of interviews, the school's way of instilling Javanese noble values to students in extracurricular wayang activities, namely: 1) always instilling good behavior in students, the teacher's attitude becomes an example for students, 2) habituation of behaving politely to everyone and guided by religion in every behavior 3) guidance on the importance of preserving the art of puppetry.

Javanese cultural values are instilled and respected in elementary schools, starting from the family and the surrounding environment through the cultivation of character. The noble values that can be enjoyed by students are part of the goal of implementing the puppetry art extracurricular activities. In Endraswara's opinion (2006: 23) describes the cultivation of Javanese character through several forms, namely the formation of harmony morals, the formation of morals for the virtues of life, the formation of good manners, and the formation of selfcontrol characteristics [10].

Some of the noble values of Javanese culture above show the Javanese view of life that emphasizes inner peace, harmony, and balance of life as well as an attitude of accepting everything that happens under God's power. Wayang for Javanese people functions not only as a spectacle but also as a guide because it contains several teachings of values derived from Javanese cultural teachings specifically for the community (Setyawan, 2020) [21]. Javanese society highly upholds the principles of life and manners to respect each other as they should be respected. Javanese people believe that all bad actions they do will get the fruit of those bad deeds. This value can be taught to students through various stories in the art of puppetry that can be related to students' daily lives.

\section{c. Evaluation}

Evaluation activities are an important part of implementing a program, evaluation becomes a benchmark for the process in assessing the results of an activity undertaken, in this case, the art of puppetry extracurricular activities. The puppet extracurricular evaluation activities are carried out at the initial meeting of the semester, based on the results of interviews with extracurricular teachers stating that the initial semester meeting discusses all general extracurricular activities from schedules, places to targets, and missions of the extracurricular art of puppetry. This is done so that the puppet show extracurricular have clear objectives and are effective in its implementation.

Based on the results of interviews and documentation, the evaluation carried out on the extracurricular activities of puppetry is a one-semester evaluation. This evaluation activity involves the principal, school committee, and extracurricular teachers. The purpose of evaluating each semester is to determine whether there are obstacles and shortcomings during extracurricular activities carried 
out. Evaluation is also carried out at every training activity that takes place, the extracurricular art teacher of puppetry conducts final evaluation activities so that what is lacking in students is immediately followed up. In general, the evaluation of puppetry extracurricular activities is good.

Obstacles in implementing puppetry extracurricular activities are 1) limited budget funds make schools unable to meet all the needs of activities 2) when students start to get bored in puppetry art activities it will hinder extracurricular activities 3) minimal training time and many stories in puppetry art. The efforts made by the school in overcoming the obstacles contained in the extracurricular activities of the puppetry art, namely: 1) involving the parents of students in these activities. 2) fulfillment of facilities and infrastructure. 3) instilling students to develop themselves so as not to stand idly by the trainer in material related to puppetry 4) habituation of Javanese noble values in school activities.

\section{CONCLUSION}

Based on the results of data analysis and discussion, it can be concluded that the implementation of puppetry extracurricular activities needs to be introduced through extracurricular activities to students so as not to lose the superior cultural arts and contain lots of moral and educational values. The Javanese cultural tradition of wayang kulit which is recognized by UNESCO as the Master Piece of Heritage of the World is one of the reasons for the importance of preserving and educating puppetry students. The puppet extracurricular is one of the interesting extracurricular activities because, in addition to the knowledge of the elements of puppetry art, extracurricular activities can also be used as character education or the cultivation of Javanese noble values that come from wayang stories.

This research is expected to provide an understanding of the importance of cultivating the noble values of Javanese culture, especially in puppetry in elementary schools. The results of this study are expected to be used as a source of reference that can provide information, understanding, and insight to all readers, especially for future researchers who will conduct similar research with this research in the future.

Based on the results of the study, the results show that puppetry extracurricular activities have a good impact on the character education of cultural noble values. Therefore, the extracurricular implementation of the art of puppetry can be used as a tool that can help students learn the values of life through storytelling. Thus, there are several recommendations from this study, namely: 1) Recommendations for other researchers, namely the research conducted in this study only reveals a small part of the problems related to the noble value education of Javanese culture. In this case, there are still many factors that can affect the extracurricular implementation process that has not been disclosed in this study. For this reason, it is suggested to the next researcher who is interested in conducting further studies or research so that it is carried out better; 2) Preservation of Javanese culture in school activities to be more active so that students can have the knowledge and a sense of interest in the local culture.

\section{AUTHORS' CONTRIBUTIONS}

Autor's contribution to the research is as a researcher, writer, and person in charge of carrying out research activities on puppet art extracurricular for education, noble values of Javanese culture, in elementary schools. The results of this study are expected to be used as a source of reference that can provide information, understanding, and insight to all readers, especially for future researchers who will research in the future.

\section{ACKNOWLEDGMENTS}

During the completion of writing this article, the author has received a lot of help from various parties, both directly and indirectly. For that, with all humility, the author would like to express his deepest gratitude to all those who helped.

\section{REFERENCES}

[1]. A Ciptoprawiro, Filsafat Jawa, Jakarta: Balai Pustaka, 2000.

[2]. A Muhammad, Perencanaan Pembelajaran Pendidikan Dasar", Jurnal Ilmiah Pendidikan, 2009 Vol. 1. No. 2

[3]. A Rachmadian, Pengaruh Masuknya Budaya Asing Terhadap Pelestarian Kebudayaan Tari Tradisional Wayang Topeng Malangan Di Malang Raya, Jawa Timur, Jurnal Pariwisata Pesona, 2019, Vol. 2

[4]. A Rizem, Atlas tokoh-tokoh wayang, Jogjakarta : Diva press, 2012.

[5]. B Grahita, "Identification of The Character Figures Visual Style in Wayang Beber of Pacitan Painting", International Journal of Asia Digital Art and Design, 2014.

[6]. B. W. Setyawan, "Environment Preserving Character on Wayang Story Dewa Ruci: an Ecological Literature Study", Jurnal Kata, 2020, Vol.4. No. 1

[7]. Benninga, Berkowitz, Kuehn, \& Smith, "The Relationship Of Character Education Implementation And Academic Achievement In Elementary Schools (Electronic Version)". Journal of Research in Character Education, 2003, Vol. 1. No 1 
[8]. Brits, "Exploring the use of puppet shows in presenting nanotechnology lessons in early childhood education". International Journal for Cross-Disciplinary Subjects in Education (IJCDSE). 2014, Vol 5. No. 4

[9]. D Sulaksono, \& KSaddhono, "Ecological Concept of Wayang Stories and the Relation with Natural Conservation in Javanese Society", Journal of KnE Social Sciences, , 2018, Vol 3. No. 9

[10]. Danoebroto, Model pembelajaran matematika berbasis pendidikan multicultural, Jurnal Pembangunan Pendidikan Fondasi dan Aplikasi, 2012, Vol. 1. No. 1

[11]. Divya, "Study to assess the effectiveness of puppet show on knowledge regarding selected mosquitoborne disease among children in selected village at Nellore", International Journal of Recent Scientific Research, 2015, Vol. 6. No 12.

[12]. E Sugiarto, Menyusun Proposal Kualitatif: Skripsi dan Tesis, Yogyakarta: Suaka Media, 2015.

[13]. H Kridalaksana, dkk, Wiwara: Pengantar Bahasa dan Kebudayaan Jawa, Jakarta: Gramedia, 2001.

[14]. H. K. Surtikanti, A Syulasmi, \& N Ramdhani, "Traditional Knowledge of Local Wisdom of Ammatoa Kajang Tribe (South Sulawesi) about Environmental Conservation. Journal of Physics: Conference Series, 2017, Vol. 8. No. 5

[15]. J Clifton, \& C Majors, "Culture, Conservation, and Conflict: Perspectives on Marine Protection Among the Bajau of Southeast Asia", Society \& Natural Resources: An International Journal, 2012, Vol 7. No. 25

[16]. K. Foley, "The Ronggeng, the Wayang, the Wali, and Islam: Female or Transvestite Male DancersSingers Performers and Evolving Islam in West Java", Asian Theatre Journal, 2015, Vol. 32. No. 6

[17]. M Nugroho, "Pendidikan Islam Berwawasan Multikultural; Sebuah Upaya Membangun Pemahaman Keberagamaan Inklusif pada Umat Muslim dalam Mudarrisa", Jurnal Kajian Pendidikan Islam, 2016, Vol. 8. No. 1.

[18]. M Syafitri, Sahyar, \& Derlina, Development of Learning Devices Through Scientific Inquiry Model Based on Javanese Culture to Improve Students' Science Process Skills and Self-Efficacy, Journal of Education and Practice. 2017, Vol. 8. No 18
[19]. M.C Ricklefs, "Islamisation and its Opponents in Java: A political, social, cultural and religious history 1930 to the present", NUS Press, Singapore.

[20]. Mulyono, Manajemen Administrasi \& Organisasi Pendidikan, Jogjakarta: Ar-Ruzz Media, 2009.

[21]. Parikesit, "3D Wayang Kulit: Traditional shadow puppetry meets modern display technology". International Journal of Arts and Technology, 2016, Vol. 9. No. 2

[22]. R Supangah, Bothekan Karawitan I. Jakarta: Masyarakat Seni Pertunjukan Indonesia, 2002.

[23]. S Amri, Sinar, A. Saragih, "Depreciation of Understanding Lexicon in Traditional Wedding Ceremony in South Tapanuli Medan, European Journal of English Language and Literature Studies, 2016,Vol. 3. No. 4 pp.49

[24]. S Endraswara, Budi Pekerti Jawa: Tuntunan Luhur Budaya Adiluhung, Yogyakarta: Buana Pustaka, 2006

[25]. S Purwanto, "Internalisasi Nilai-Nilai Religius Dalam Pendidikan Dalang Wayang Kulit (Studi Kasus Di Sanggar Seni Wayang Kulit Padharasa Salatiga)", Tesis, Salatiga: Institut Agama Islam Negeri Salatiga, 2019.

[26]. Sartini, "Explores Local Wisdom of Indonesia, a Philosophical Study", Journal of Philosophy, 2012, Vol. 37. No. 2

[27]. Sugiyono, Metode Penelitian Pendidikan Pendekatan Kuantitatif, Kualitatif dan $R \& D$. Bandung: alfabeta, 2017.

[28]. Supriyono, Pedhalangan. Jakarta: Departemen Pendidikan Nasional, 2008.

[29]. T Susiatik, "Urgency of Character Education Towards Resocialization Effort of Child Prisoners", KLIBEL: International Journal of Business, Economics, and Law, 2017 Vol. 3.

[30]. Wardani, E Nugraheni, Et Al, "Learning Media Using Wayang Wong To Introduce Local Wisdom Of Javanese Culture For The Student Of Indonesian Language For Fotrign Learners", Journal Of Arts, Science \& Commerce, 2016, Vol 8

[31]. Widodo, "The influence of Javanese Culture on The Education Curriculum in Indonesia", Journal of Education and Practice, , 2013, Vol. 4 No. 19 